\title{
In-vitro and in silico activity of Cyamopsis tetragonoloba (Gaur) L. supercritical extract against the dengue- 2 virus
}

\author{
Sulochana Kaushik ${ }^{1}$-Samander Kaushik ${ }^{2} \cdot{\text { Ramesh } \text { Kumar }^{3} \text { - Lalit Dar }}^{3}$ • \\ Jaya Parkash $\operatorname{Yadav}^{1}$ (D)
}

Received: 23 June 2020/Accepted: 19 August 2020/Published online: 31 August 2020

(C) Indian Virological Society 2020

\begin{abstract}
Our health and wealth are highly influenced by a number of viruses. Dengue is one of them having a global influence in absence of vaccines and antiviral. WHO suggested that the morbidity of dengue is increasing more than 6 times from 0.5 million in 2010 to over 3.34 million in 2016, following a sharp increase in 2019. The aim of the present study is to check the in vitro and in silico antidengue activity of Cyamopsis tetragonoloba supercritical extract in cell lines. The optimum yield of supercritical extract was obtained $0.13 \mathrm{~g} / 10 \mathrm{~g}(1.3 \% \mathrm{w} / \mathrm{w})$ at $40{ }^{\circ} \mathrm{C}$ temp and $15 \mathrm{MPa}$ pressure and further characterized by GC-MS. The antiviral assay was performed on C6/36 cell lines with 100 copies of dengue- 2 virus and maximum nontoxic dose $(31.25 \mu \mathrm{g} / \mathrm{ml})$ of supercritical extract and their effect was detected by real-time RT-PCR. This study revealed that $C$. tetragonoloba supercritical extract inhibited the dengue-2 virus (99.9\%). GC-MS analysis of $C$. tetragonoloba supercritical extract showed the presence of 10 compounds. The major compounds identified were Hexadecanoic acid, 15-methyl-methyl ester (24.498\%); 9,12-octadecadienoyl chloride, $(z, z)$ - (23.718\%); methyl dodecanoic acid (13.228\%); methyl-stearate (8.696\%); Tridecanoic acid, 12-methyl-, methyl-ester $(8.426 \%)$, dodecanoic acid $(6.102 \%)$. The study reveals that $C$. tetragonoloba can be exploited to develop an effective,
\end{abstract}

Jaya Parkash Yadav

yadav1964@rediffmail.com

1 Department of Genetics, Maharshi Dayanand University, Rohtak, Haryana 124001, India

2 Centre for Biotechnology, Maharshi Dayanand University, Rohtak, Haryana 124001, India

3 Department of Microbiology, All India Institute of Medical Sciences, New Delhi 110029, India inexpensive, and specific anti-dengue. The molecular docking study demonstrated the binding energy of 1,2benzenedicarboxylic acid, bis(2-methylpropyl) ester $(-4.1 \mathrm{kcal} / \mathrm{mol}), \quad 9,12$-octadecadienoyl chloride $(z, z)(-4.0 \mathrm{kcal} / \mathrm{mol})$ ligands were higher than others. It is concluded that $C$. tetragonoloba can play a major role to inhibit dengue-2 virus.

Keywords Dengue virus $\cdot$ C. tetragonoloba $\cdot$ Supercritical extract $\cdot$ GC-MS $\cdot$ Molecular docking

\section{Introduction}

Dengue is a very notorious mosquito-borne viral infection, belongs to the family Flaviviridae, which contains at least seventy-two viruses including; Zika, Yellow fever, Japanese encephalitis, and West Nile viruses. Dengue is an enveloped, single-stranded, positive-sense RNA virus, transmitted by Aedes aegypti and Aedes albopictus mosquitoes. There are four serotypes of dengue virus circulating in various parts of the World. Dengue is very dangerous since its origin but its prevalence has increased significantly within the last two decades. Although there is no specific surveillance, World Health Organization (WHO) suggested that more than 100 countries from Asia, Africa and some parts of Europe, South and North America are affected by dengue virus [38]. The number of dengue cases reported to WHO increased by $\sim 6$ times from $<$ 0.5 million in 2010 to over 3.34 million in 2016, following a sharp increase in 2019 [3]. At present, there is no effective treatment for dengue. Medicinal plants area source for the treatment of common to life-threatening diseases since civilization. Herbal medicine can be alone used for treatment or increase the therapeutics potential 
when used along with conventional antiviral medicines [13]. Many herbs are being routinely used against DENV infection as an alternative approach to reduce disease symptoms [11]. The discovery of natural drugs will be more universal, modified, and involves sensible use of modern and ancient skills of therapeutics in a corresponding way so that the patient and community get the maximum benefits [23]. The present study is focused on Cyamopsis tetragonoloba (L.) Taub (guar), which is commonly known as cluster bean belongs to the family Fabaceae. It is a small (2-4 feet), drought-resistant legume plant cultivated in semi-arid regions of India and Pakistan. The plant seeds are rich sources of their nutritive values viz vitamins, amino acids, flavonoids and phenolic compounds [18]. C. tetragonoloba used as an herbal medicine for dyspepsia, anorexia, digestive aid, cure inflammation, sprains, arthritis, anti-secretory, and anti-oxidant and antibacterial [15]. Guar gum is an herbal medicine that is used for treating cancer and diabetes which is also used as a dietary supplement. It has properties as anti-microbial, anti-tumor, and anti-inflammatory. The leaves of gaur used in asthma, and to treat night blindness, constipation, cough, and Vata [36]. Several secondary compounds were present in gaur seeds and works have been carried out $[1,6]$. The present study aims to analyse the in vitro and in silico antidengue potential of $C$. tetragonoloba supercritical extract (SFE) in animal cell culture model and to analyse the secondary compound in the extract by gas chromatography-mass spectrometry (GC-MS).

\section{Materials and methods}

\section{Chemicals and reagents}

An in vitro study was done in C6/36 cell with the help of minimum essential medium (MEM, Batch No. 0000319279), streptomycin sulphate $(100 \mu \mathrm{g} / \mathrm{ml}$, Hi-Media, Batch No. 0000187551), Penicillin (100 U/ml, SigmaAldrich Batch No. BCBN 3112V), Trypsin (Hi-Media Batch No. 0000285329) and Fetal Calf Serum (FCS, Gibco NV, USA, Batch No. 1584260). Cell viability/cytotoxicity was performed by 3-(4,5-dimethylthiazol-2-yl)-2,5diphenyltetrazolium bromide (MTT, Hi-Media, Batch No. 0000263610). Analysis of anti-dengue assay was done using the commercially Geno-Sen's Dengue S1-S4 PCR kit that contains a buffer, virus standard, enzymes, dNTPs, dengue specific primer, and probes.

\section{Collection of plants materials}

C. tetragonoloba was selected on the basis of traditional knowledge and collected from agriculture fields of village
Majra (Dubaldhan), district Jhajjar, Haryana, India. The geographical location of the collection site is Latitude $28^{\circ}$ $41^{\prime} 15.432^{\prime \prime} \mathrm{N}$ and Longitude $76^{\circ} 52^{\prime} 47.028^{\prime \prime}$ E. Plant samples were transported to the laboratory in sterile bags. After proper identification by a taxonomist, the plant material was washed with tap water to remove the dust and rinse with distilled water. The material was stored in a shade and dry place at room temperature and minced after dry.

\section{Preparation of supercritical fluid extraction of $C$. tetragonoloba}

C. tetragonoloba extract was prepared by using Supercritical Fluid Extraction Machine (Applied Separation Inc. U.S.). Ten grams of the plant powder was loaded into the stainless steel extraction cell of the machine. The $\mathrm{CO}_{2}$ used as a solvent in SFE. The flow rate was maintained at $1.6 \mathrm{ml} / \mathrm{min}$ with static-dynamic mode $(1 \mathrm{~h} \mathrm{static}$ and 30 min dynamic mode). The method of extraction of the plant was standardized and optimized at $40{ }^{\circ} \mathrm{C}$ temperature and 150 bar pressure. The obtained SFE extract was lyophilized, weighed and stored at $4{ }^{\circ} \mathrm{C}$ for further use.

\section{Determination of cell viability by MTT assays}

The maximum non-toxic dose (MNTD) of C. tetragonoloba supercritical fluid extracts was determined on $90 \%$ confluent C6/36 cells. Approximate, $1 \times 10^{5}$ cells/ well were seeded into 96-well flat bottom plate (Nunc, Thermo Fisher Scientific, and the USA) and incubated at $28{ }^{\circ} \mathrm{C}$ in a $5 \% \mathrm{CO}_{2}$ incubator overnight. After $90 \%$ confluency of $\mathrm{C} 6 / 36$ cells, the medium was removed and the cells were treated with a serial dilution of different concentrations (ranging from $1000 \mu \mathrm{g} / \mathrm{ml}$ to $15.62 \mu \mathrm{g} / \mathrm{ml}$ ) of C. tetragonoloba supercritical fluid extracts in triplicates. In the negative control, $100 \mu \mathrm{l}$ of the growth medium was used. After incubation of $96 \mathrm{~h}$, the medium of each well was replaced with $10 \mu \mathrm{l}$ of MTT, 3-(4,5-dimethylthiazol-2yl) 2, 5-diphenyl tetrazolium bromidesalt solution $(5 \mathrm{mg} /$ $1 \mathrm{ml}$ in PBS, as stock) and again incubated for $3 \mathrm{~h}$ at $28{ }^{\circ} \mathrm{C}$ in $5 \% \mathrm{CO}_{2}$ incubator. MTT solution was discarded without disturbing the cells and $100 \mu \mathrm{l}$ of DMSO was added into each well to stop the reaction. The 96 wells plate was continuously shaken until all formazan crystals dissolved. Cell viability was determined with the help of absorbance values obtained by using a microplate reader (Bio-Rad, USA) at $595 \mathrm{~nm}$.

\section{Cell culture and virus isolation}

The Aedes cell line C6/36 (ATCC ${ }^{\circledR}$ CRL-1660 TM) was maintained at $28{ }^{\circ} \mathrm{C}$ in $5 \% \mathrm{CO}_{2}$ incubator with the help of 
minimum essential medium (MEM) supplemented with $10 \%$ fetal calf serum (FCS), 2 mML-glutamine, penicillin $(100 \mathrm{U} / \mathrm{ml})$ and streptomycin $(100 \mu \mathrm{g} / \mathrm{ml})$. A total of $500 \mu \mathrm{l}$ of an appropriate dilution of dengue- 2 standard strain was inoculated onto confluent $\mathrm{C} 6 / 36$ cells in $25 \mathrm{~cm}^{2}$ tissue culture flask and then incubated at $28{ }^{\circ} \mathrm{C}$ incubator with $5 \% \mathrm{CO}_{2}$. After $45 \mathrm{~min}$, the virus growth media was added and the cells were further incubated. Even after proper incubation, no cytopathic effect or no plaque formation takes place. Then, flasks stored in the deep freeze and the lysates were harvested and viral RNA was extracted by using a commercial QIAmp Viral RNA mini kit (Qiagen, Germany) according to the manufacturer's protocol. The viral titer of the dengue- 2 virus was determined in cell culture lysate by quantitative real-time RTPCR (ABI-7500 Real-time) along with known standards of dengue, which contains $10^{1}-10^{5}$ copies/ml (S1-S5) provided by Geno-Sen's Dengue 1-4 commercial kit. A calibration curve was plotted with positive control. The 100 copies/ml of dengue- 2 viruses were determined form the lysate, for further anti-viral experiments in the present study.

\section{In vitro anti-dengue assay}

The anti-viral assay was initiated by incubating 96 wells plate having a monolayer of $\mathrm{C} 6 / 36$ cells. The simultaneous mode of treatment was carried out to perform the anti-viral assay. The $100 \mu \mathrm{l}$ of viral suspension of DENV-2 (100 copies/wells) was treated with an equal volume of the non-toxic dose $(31.25 \mu \mathrm{g} / \mathrm{ml})$ of $C$. tetragonoloba plant extract was inoculated in 96 well plates. The plate setup included a cell control, a virus control (cells with back titration of 10, 100 and 1000 copies of dengue-2 virus) and cell viability control (cell with MNTD of $C$. tetragonoloba extracts) as well as experimental well (cell with 100 copies of the dengue- 2 virus treated by MNTD of $C$. tetragonoloba extracts) in 96 replica plate. After that, the plate was sealed with parafilm and incubated on ice for $45 \mathrm{~min}$ and shaken gently after every $10 \mathrm{~min}$. The mixture from each well of the replica plate was transferred into respective wells of the experimental plate without disturbing the C6/36 cells layer of experimental plate. After inoculation, the experimental plate was sealed with parafilm and incubates for $45 \mathrm{~min}$ at $28{ }^{\circ} \mathrm{C}$ in the $\mathrm{CO}_{2}$ incubator. The medium was aspirated from the experimental plate wells. Then, the virus growth medium (VGM) was added without disturbing the cells layer in all wells (including cell control wells). The experiments were carried out in triplicates. Further, the 96-well plate was incubated at $28{ }^{\circ} \mathrm{C}$ in a $\mathrm{CO}_{2}$ incubator for 7 days. After proper incubation, the plate was frozen at $-70{ }^{\circ} \mathrm{C}$ and the lysates were harvested and RNA was extracted from each aliquot and quantifies the virus to study the antiviral effect of $C$. tetragonoloba extracts.

\section{Anti-viral assay by qRT-PCR}

TaqMan probe chemistry-based Real-time RT-PCR was performed to determine the potential of $C$. tetragonoloba on DENV-2. The commercially available Geno-Sen's Dengue S1-S4 PCR kit was used to perform the antiviral assay on ABI 7500 real-time PCR instruments. The commercially kit contains a specific master mix for specific amplification and quantification of dengue viruses. All the PCR reagents were thawed. The master mix was prepared following the kit manufacturer's instructions. After that, PCR tubes were prepared by adding $10 \mu \mathrm{l}$ master mix and $15 \mu \mathrm{l}$ of extracted RNA from each lysate from cell/negative control, virus/positive control, experimental/dengue- 2 virus treated by MNTD of $C$. tetragonoloba extracts, and standards (Dengue $S$ 1-5). Then, all the reagents were mixed properly by pipetting up and down in the PCR tubes. Then the amplification tubes were closed and transferred into the ABI 7500 real-time thermocycler. The reaction conditions of PCR were as follows: reverse transcription at $50{ }^{\circ} \mathrm{C}$ for $15 \mathrm{~min}$, denaturation at $95{ }^{\circ} \mathrm{C}$ for $10 \mathrm{~min}$, as followed by 45 cycles of denaturation at $95{ }^{\circ} \mathrm{C}$ for $15 \mathrm{~s}$, annealing at $55^{\circ} \mathrm{C}$ for $30 \mathrm{~s}$ and a final extension step at $72{ }^{\circ} \mathrm{C}$ for $15 \mathrm{~s}$. The fluorescence emission data were collected during the annealing step.

\section{Data Analysis}

The percentages of cell viability of supercritical plants extract concentrations and anti-dengue data was analyzed by Microsoft Excel 2007 with the help of Tukey's test (each treatment mean value different from each other and compared to control). The results were expressed as mean \pm standard deviations. The cell viability of plant was calculated as:

$$
\begin{aligned}
\text { Cell viability }(\%)= & \frac{\text { Absorbance treated cell }- \text { Absorbance blank }}{\text { Absorbance cells control }- \text { Absorbance blank }} \\
& \times 100
\end{aligned}
$$

\section{Phytochemical analysis using gas chromatography- mass spectrometry (GC-MS)}

Phytochemical analysis of $C$. tetragonoloba SFE extract was carried out using GC-MS analyser (BRUKER SCION 436-GCSQ). Helium (99.9\%) was used as carrier gas at a flow rate of $1.5 \mathrm{ml} / \mathrm{min}$ in split mode. The RESTEK Rtx ${ }^{\circledR}$ 5 (cross bond ${ }^{\circledR} 5 \%$ diphenyl/95\% dimethyl polysiloxane) column of suitable dimensions was used. The extract was 
dissolved in methanol solvent (HPLC grade) and filtered through Whatman filter paper $0.22 \mu \mathrm{m} .1 \mu \mathrm{L}$ of the plant sample was injected into the column with an inlet temperature of $280^{\circ} \mathrm{C}$. The conditions were initially programmed at temperature $72{ }^{\circ} \mathrm{C}$ hold for 2.5 min and then further amplified at a rate of $10{ }^{\circ} \mathrm{C}$ per minute until reached up to $320^{\circ} \mathrm{C}$; hold for $1 \mathrm{~min}$. Total running time was $23.7 \mathrm{~min}$ including $3 \mathrm{~min}$ solvent delay. The mass spectrum of compounds present in the extract was obtained by electron ionization at $70 \mathrm{eV}$ and the detector operates in scan mode 30 to $500 \mathrm{Da}$ atomic units. The ionization spectra were matched with the NIST (National Institute of Standards Technology) library to identify the compounds along with their area and percentage of the total.

\section{Preparation of ligands and protein structure}

The non-structural proteins of DENV-2, NS1 (PDB IDs: 4O6B) were downloaded from PDB (protein data bank) because of better resolution and used a target for docking. The 3D structures of plant ligands were downloaded from PubChem. Ten ligands were selected for docking were Methyl dodecanoic acid (PubChem ID:5282687), Dodecanoic acid, (PubChem ID:3893), tridecanoic acid 12-methyl-, methyl-ester (PubChem ID: 21204), 3,7,11,15tetramethyl-2 hexadecen-1-ol (PubChem ID: 5366244), 1,2-benzenedicarboxylic acid, bis(2-methylpropyl) ester (PubChem ID: 6782), Hexadecanoic acid, 15-methyl-, methyl ester (PubChem ID: 522345) 9,12-octadecadienoyl chloride, $(z, z)-$, (PubChem ID:9817754), methyl stearate, (PubChem ID: 8201), tritetracontane (PubChem ID: 522398), tetracontane, 3,5,24-trimethyl (PubChem ID: 41344). The binding orientation and affinity of the ligand to target was predicted by 1-Click docking tool.

\section{Results}

\section{Optimization of supercritical condition for extraction}

The maximum yield (1.3\%) of a supercritical extract of $C$. tetragonoloba plant was obtained at $40{ }^{\circ} \mathrm{C}$ temperature and $15 \mathrm{MPa}$ pressure of the SFE extractor machine.

\section{Maximum non-toxic dose (MNTD) of plants}

The $31.25 \mu \mathrm{g} / \mathrm{ml}$ was maximum non- toxic dose of $C$. tetragonoloba found, when cell viability assay was performed with the C6/36 cell-line. The MTT assay was versatile and to determine the cell viability and cytotoxicity of the cells. The result of cell viability has been shown in Fig. 1.

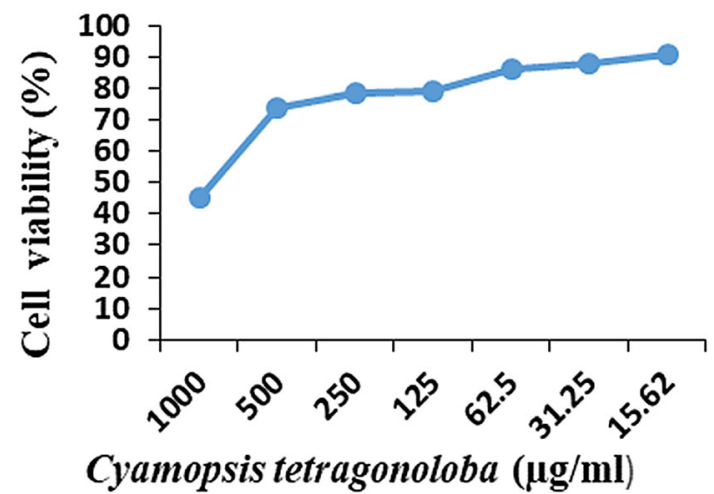

Fig. 1 Maximum non- toxic dose of C. tetragonoloba

\section{Quantitative antiviral assay}

This study revealed that the $C$. tetragonoloba supercritical extract inhibited the $99.9 \%$ dengue- 2 virus. The percentage of reduction in viral load of an active extract was compared with the positive control containing the same copy number of dengue- 2 viruses, which had $1.76 \times 10^{6}$ copies $/ \mathrm{ml}$ of the virus after 7 days post-infection in the absence of any extract. The amplification curve was plotted with back titration which contains S1-1000 copies, 10 copies, 100 copies with infected plant extract. The $C$. tetragonoloba CT value was compared to virus control CT value (18) which contains 100 copies. If CT value increases then the virus decrease. An amplification curve depicting the antidengue activity of plant $C$. tetragonoloba has been shown in Fig. 2.

\section{Phytochemical analysis using GC-MS}

Organic compounds of C. tetragonoloba were identified by GC-MS analysis and spectra result was matched with the National Institute of Standards Technology (NIST) MS

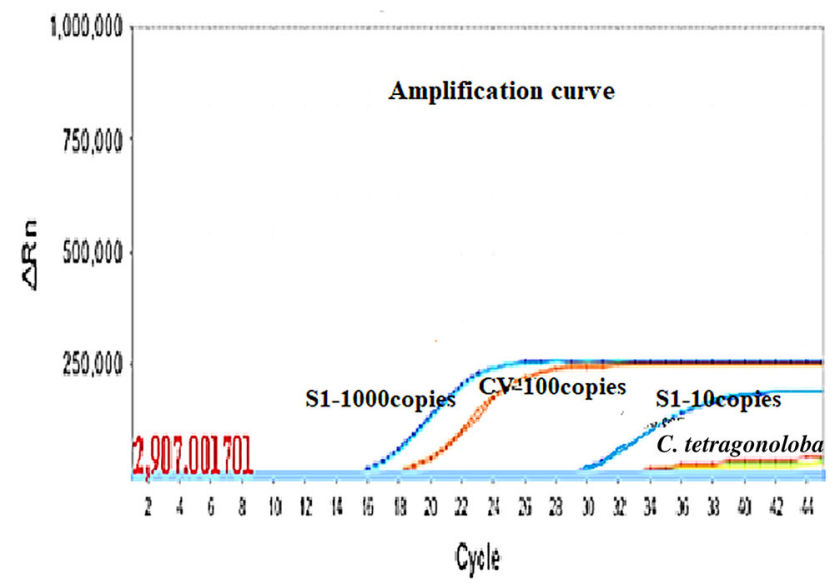

Fig. 2 Amplification inhibition curve of the dengue-2 virus by $C$. tetragonoloba SFE extract (S1- Positive control) 
MS Data Review Active Chromatogram Plot - 30/11/2016 14:54

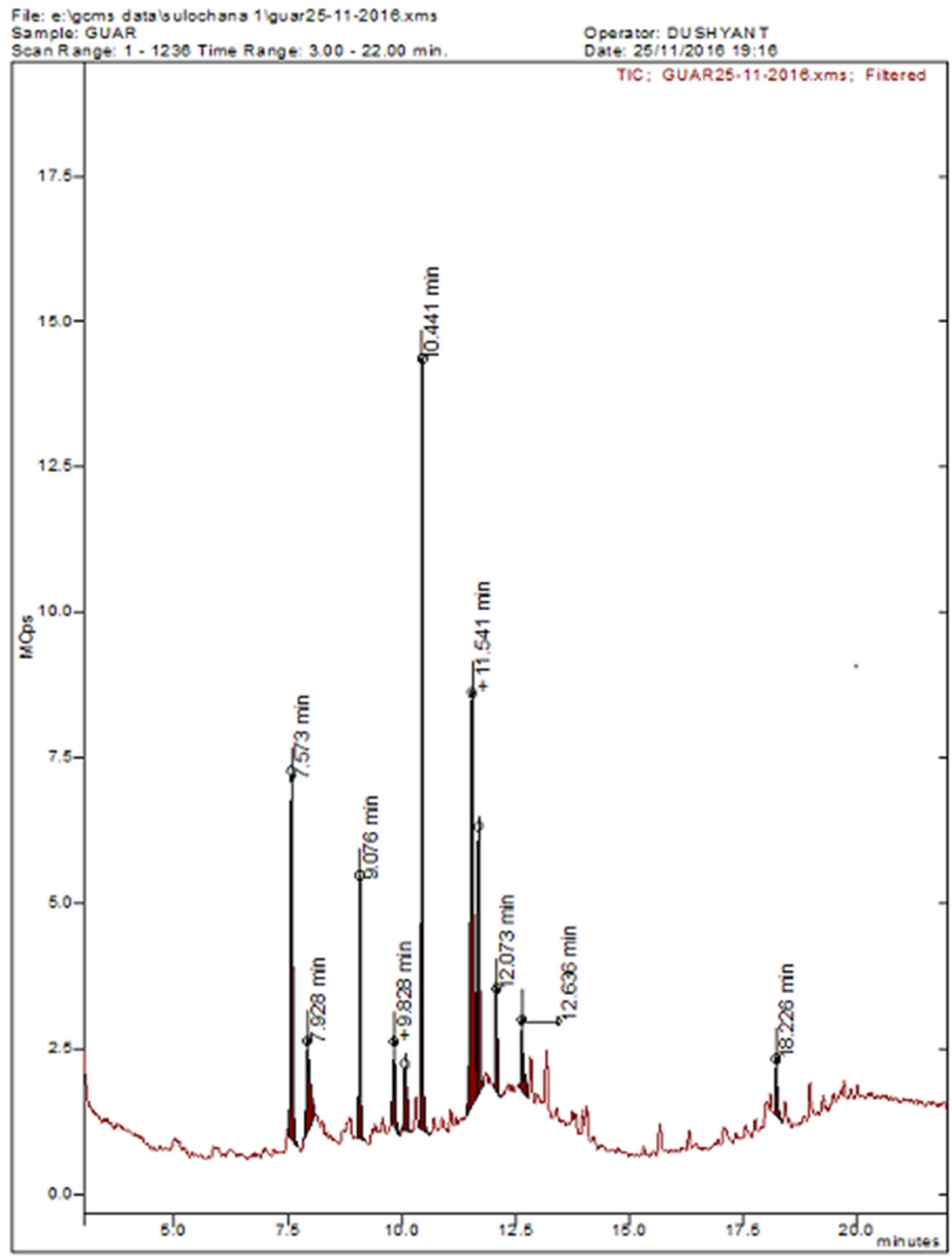

Fig. 3 GC-MS of C. tetragonoloba SFE extract

library in GC-MS. GC-MS analysis of C. tetragonoloba SFE extract showed the presence of 10 compounds when compared with the NIST database (Fig. 3 and Table 1). The major compounds identified were Hexadecanoic acid, 15-methyl-methyl ester (24.498\%); 9,12-Octadecadienoyl chloride, $(z, z)-$ (23.718); methyl dodecanoic acid (13.228\%); tridecanoic acid, 12-methyl-, methyl stearate $(8.696 \%)$; Tridecanoic acid, 12-methyl-, methyl-ester $(8.426 \%)$, Dodecanoic acid $(6.102 \%)$.

\section{Molecular docking}

Ligand shown with blue color (ball and stick) and NS1 with grey color (Ribbon). The binding affinity is shown in bracket along with the name of respective compound and interacting residues illustration between protein (yellow and green) and ligand (white). The hydrogen bonding interaction between the ligands and protein was given in Fig. 4. The higher binding energy obtained from the 
Table 1 Components detected in C. tetragonoloba bean SFE extract

\begin{tabular}{|c|c|c|c|c|c|c|}
\hline $\begin{array}{l}\text { S. } \\
\text { No }\end{array}$ & RT & Name of compounds & $\%$ Area & Class of compound & Formula & MW \\
\hline 1 & 7.571 & Methyl dodecanoic acid & 13.228 & Fatty acid & $\mathrm{C}_{13} \mathrm{H}_{26} \mathrm{O}_{2}$ & 214 \\
\hline 2 & 7.925 & Dodecanoic acid & 6.102 & Fatty acid & $\mathrm{C}_{12} \mathrm{H}_{24} \mathrm{O}_{2}$ & 200 \\
\hline 3 & 9.079 & Tridecanoic acid, 12-methyl-, methyl-ester & 8.426 & Fatty acid & $\mathrm{C}_{15} \mathrm{H}_{30} \mathrm{O}_{2}$ & 242 \\
\hline 4 & 9.833 & 3,7,11,15-Tetramethyl-2 hexadecen-1-ol & 3.400 & Terpene alcohol & $\mathrm{C}_{20} \mathrm{H}_{40} \mathrm{O}$ & 296 \\
\hline 5 & 10.064 & 1,2-Benzenedicarboxylic acid, bis(2-methylpropyl) ester & 3.364 & Fatty acid & $\mathrm{C}_{16} \mathrm{H}_{22} \mathrm{O}_{4}$ & 278 \\
\hline 6 & 10.448 & Hexadecanoic acid, 15-methyl-, methyl ester & 24.498 & Fatty acid & $\mathrm{C}_{18} \mathrm{H}_{36} \mathrm{O}_{2}$ & 284 \\
\hline 7 & 11.541 & 9,12-Octadecadienoyl chloride, $(z, z)$ - & 23.718 & Fatty acid & $\mathrm{C}_{18} \mathrm{H}_{31} \mathrm{CIO}$ & 298 \\
\hline 8 & 11.679 & Methyl stearate & 8.696 & Fatty acid & $\mathrm{C}_{19} \mathrm{H}_{38} \mathrm{O}_{2}$ & 298 \\
\hline 9 & 12.079 & Tritetracontane & 3.420 & Fatty acid & $\mathrm{C}_{43} \mathrm{H}_{88}$ & 605 \\
\hline 10 & 12.633 & Tetracontane, 3,5,24-trimethyl- & 3.085 & Alkane & $\mathrm{C}_{43} \mathrm{H}_{88}$ & 605 \\
\hline
\end{tabular}

Fig. 4 Hydrogen bonding interaction of dengue NS1 protein with ligands. a Methyl dodecanoic acid, b dodecanoic acid, $\mathbf{c}$ tridecanoic acid, 12-methyl-, methyl-ester, d $0.3,7,11,15$-tetramethyl-2 hexadecen-1-ol, e 0.1,2benzenedicarboxylic acid, bis(2methylpropyl) ester,

f hexadecanoic acid, 15-methyl-, methyl ester, g 0.9,12-

octadecadienoyl chloride, $(z, z)-$, h methyl stearate, i Tritetracontane, j tetracontane,3,5,24-trimethyl-
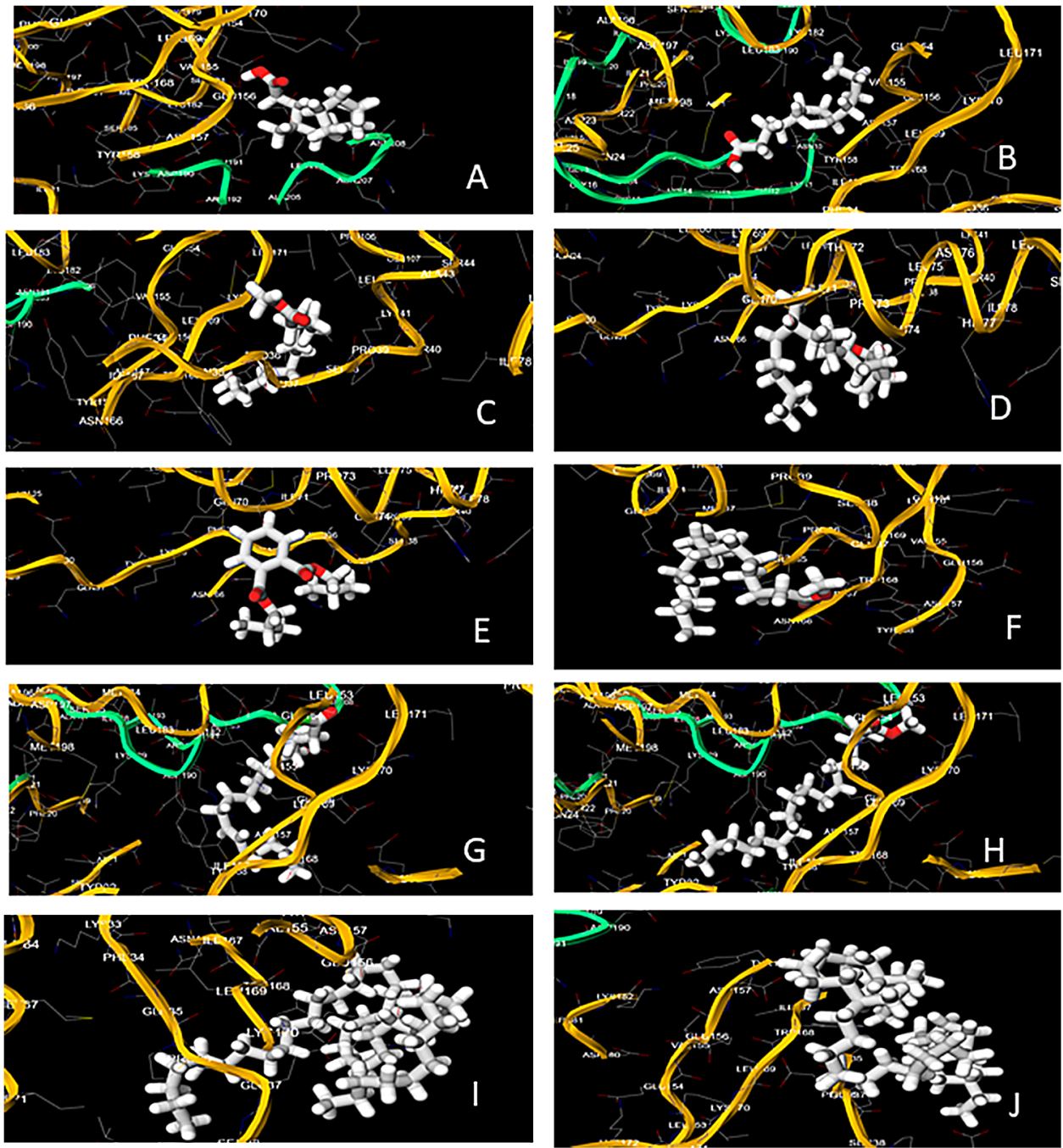

ligands at decreasing order i.e. 1,2-benzenedicarboxylic acid, bis(2-methylpropyl) ester (- $4.1 \mathrm{kcal} / \mathrm{mol})$, 9,12Octadecadienoyl chloride $(z, z) \quad(-4.0 \mathrm{kcal} / \mathrm{mol})$, dodecanoic acid, $(-3.9 \mathrm{kcal} / \mathrm{mol})$, tridecanoic acid, 12-methyl-, methyl-ester (- $3.8 \mathrm{kcal} / \mathrm{mol}), 3,7,11,15$-tetramethyl-2 hexadecen-1-ol $(-3.8 \mathrm{kcal} / \mathrm{mol})$, methyl 
dodecanoic acid $(-3.6 \mathrm{kcal} / \mathrm{mol})$, methyl stearate (- $3.0 \mathrm{kcal} / \mathrm{mol})$, Hexadecanoic acid, 15-methyl-, methyl ester $(-3.0 \mathrm{kcal} / \mathrm{mol})$, tetracontane, 3,5,24-trimethyl $(-2.5 \mathrm{kcal} / \mathrm{mol})$, and Tritetracontane $(-2.3 \mathrm{kcal} / \mathrm{mol})$.

\section{Discussion}

The viral outbreaks like Crimean Congo hemorrhagic fever, Ebola, Lassa fever, Marburg virus, SARS- CoV, MERS-CoV, Nipah, Zika virus, Rift Valley fever virus and now COVID-19 are some evidence of our disaster. Nipah virus, Zika virus, and COVID-19 outbreaks in India are a few episodes [17, 19, 32, 34]. For the effective control of a viral outbreak, there should be a rapid, sensitive, specific and cost-effective diagnosis assay should be present. Molecular diagnosis assays are the best diagnostic methods as compared with other methods [2, 4, 7, 8, 31]. Dengue is still a big challenge for most of the countries and has become a global health issue. There are no commercial anti-viral drugs available in the market against it. Medicinal plants or their derivatives are of a crucial therapeutic aid for various diseases [20, 26, 37]. Drugs such as morphine, quinine, quinidine, aspirin, colchicines, digoxin, artemisinin, taxol, tubocurarine, ephedrine, vincristine, and vinblastine have been derived from several medicinal plants are used in the treatment of the different type of diseases. Therefore, research on medicinal plant extracts and their bioactive compounds which could be safer and cheaper than synthetic drugs is gaining importance. Many other studies have demonstrated the value of medicinal plants against dengue serotypes [16, 21, 28].

In the present study, we demonstrated that the supercritical extracts of $C$. tetragonoloba show highly significant anti-viral activity against the dengue- 2 virus quantitatively with the help of a real-time PCR assay. Supercritical fluid extraction (SFE) is a new extraction technique that is more accurate, safe, reliable, and time-saving, with a higher yield and better-purified compounds compared to conventional methods. The recently reported TaqMan amplification system works the one-step RT-PCR protocol and is a sensitive method for quantification. A previous study suggested that the MNTD of methanolic extracts of $A$. paniculata and $O$. sanctum are 0.050 and $0.100 \mathrm{mg} / \mathrm{ml}$ have anti-dengue activities against DENV-1 serotype on the Vero E6 cells [35]. In another study reported the MNTD of methanolic extracts of $A$. paniculata and $O$. sanctum as $0.020 \mathrm{mg} / \mathrm{ml}$ and $0.023 \mathrm{mg} / \mathrm{ml}$ are effective against DENV-1 on HepG2 cells [22]. In the present study, the MNTD of C. tetragonoloba extract was found $31.25 \mu \mathrm{g} / \mathrm{ml}$ effective against the DENV-2 virus on C6/36 cells. A study demonstrated that silver nanoparticles of Andrographis paniculata, Phyllanthus niruri and Tinospora cordifolia showed potent inhibitory activity against the chikungunya virus [33]. For the antiviral assay, a real-time PCR was performed using either fluorescent hydrolysis (TaqMan) probes, as the TaqMan based RT-PCR assay is more specific than an SYBR green-based RT-PCR assay [29].

C. tetragonoloba bean contains common chemical components e.g. fatty acids, and amino acid. Beans of gaur contain high contents of fats, proteins and carbohydrates. A study demonstrated that the bean of gaur had a high percentage of linoleic acid and the ethanolic extract of $\mathrm{C}$. tetragonoloba bean showed antioxidant and anticancer activity. Gaur plant has been shown to be an effective the hypocholesterolemic agent [5, 24]. The C. tetragonoloba showed an anti-diabetic effect, anticoagulant activity, antiulcer, hemolytic activity, anti-asthmatic activity, anti-inflammatory activity, antibacterial, hypoglycemic and hypolipidemic effect $[10,12,25,27,30]$. In the present study, the supercritical extract of gaur contain Hexadecanoic acid, 15-methyl-, methyl ester (24.498\%), 9,12-octadecadienoyl chloride, $(z, z)-(23.718)$, Dodecanoic acid, methyl (13.228\%), are the major compounds found in SFE extract of $C$. tetragonoloba. In previous study, the aqueous and methanol extract of $C$. tetragonoloba contains major constituents that were more inositol and 7-tetradecenal, (Z), stigmasterol, 10,12-hexadecadien-1-ol and 9,12-octadecadienoyl chloride, $(z, z)$ and have reported antioxidant, anti-cancerous and thyroid inhibiting properties [14]. Further research on this may help in the development of medicines against the dengue virus. Molecular docking in silico method is used in drug development. In this method, phytochemicals are matched with viral targets to find interactions between the drug and disease-producing agents by using the computational method. NS1 are essential for viral replication. NS1 is the only protein that is continuously secreted by infected host cells. NS1 is found in multifunctional in nature i.e. production of infectious virus particles, by using an innovative trans-complementation system with fully functional epitope-tagged in NS1 protein, also interacts with the structural proteins, etc. Due to multifunctional in nature, NS1 protein appears as an attractive target for antiviral therapy [9]. The researchers have put great effort in search of effective molecules for targeting different structural or non-structural proteins of the dengue virus.

In conclusion, supercritical extracts of plants were used to inhibit dengue virus. The inhibition profile of $C$. tetragonoloba plant extracts for dengue-2 showed significant anti-dengue activity. The GC-MS identified natural compounds may be responsible for their inhibitory activity against dengue-2. At a result of molecular docking and in vitro study demonstrated that the $C$. tetragonoloba plant extract machanism of action is to cease the dengue replication (NS1). As anti-dengue activity is associated with $C$. 
tetragonoloba further research is required. Plant extracts and its derivatives have the potential to develop newer antidengue drugs with unique drug targets.

Acknowledgements Sulochana Kaushik acknowledges the financial support received from Maharshi Dayanand University, Rohtak for the award of University Research Scholarship.

\section{Compliance with ethical standards}

Conflict of interest The authors have no conflict of interest to declare.

\section{References}

1. Badr SE, Sakr DM, Mahfouz SA, Abdelfattah MS. Licorice (Glycyrrhiza glabra L.): Chemical composition and biological impacts. Res J Pharm Biol Chem Sci. 2013;4:606-21.

2. Bharaj P, Sullender WM, Kabra SK, Mani K, Cherian J, Tyagi V, Chahar HS, Kaushik S, Dar L, Broor S. Respiratory viral infections detected by multiplex PCR among pediatric patients with lower respiratory tract infections seen at an urban hospital in Delhi from 2005 to 2007. Virol J. 2009;6:89. https://doi.org/10. 1186/1743-422X-6-89.

3. Brady OJ, Gething PW, Bhatt S, Messina JP, Brownstein JS, Hoen AG, Moyes CL, Farlow AW, Scott TW, Hay SI. Refining the global spatial limits of dengue virus transmission by evidence-based consensus. PLoS Negl Trop Dis. 2012; 7:6(8).https://doi.org/10.1371/journal.pntd.0001760.

4. Broor S, Chahar HS, Kaushik S. Diagnosis of influenza viruses with special reference to novel H1N1 2009 influenza virus. Ind J Microbiol. 2009;49:301-7. https://doi.org/10.1007/s12088-0090054-5.

5. Chen WJ, Anderson JW. Effects of plant fiber in decreasing plasma total cholesterol and increasing high-density lipoprotein cholesterol. Proc Soc Exp Biol Med. 1979;162:310-3. https://doi. org/10.3181/00379727-162-40671.

6. Daniel M. Polypheols of some Indian vegetables. Curr Sci. 1989;58:1332-4.

7. Dhakad S, Mali PC, Kaushik S, Lal AA, Broor S. Comparison of multiplex RT-PCR with virus isolation for detection, typing and sub-typing of influenza virus from influenza-like illness cases. Ind J Med Microbiol. 2015;33:73-7. https://doi.org/10.4103/02550857.148383 .

8. Dhull D, Sharma V, Sharma Y, Kaushik S. Applicability of molecular assays for detection and typing of herpes simplex viruses in encephalitis cases. VirusDisease. 2019;30:504-10. https://doi.org/10.1007/s13337-019-00558-x.

9. El Sahili A, Lescar J. Dengue virus non-structural protein 5. Virus. 2017;9:91. https://doi.org/10.3390/v9040091.

10. Elemike EE, Tanzim S, Ekennia AC, Onwudiwe DC. Silver nanoparticles mediated by extract of Guar plant (Cyamopsis tetragonoloba), and evaluation of their photocatalytic and antibacterial properties. Adv Mater Lett. 2019;10:284-93. https://doi. org/10.5185/amlett.2018.2198.

11. Handel AS, Ayala EB, Borbor-Cordova MJ, Fessler AG, Finkelstein JL, Espinoza RX, Ryan SJ, Stewart-Ibarra AM. Knowledge, attitudes, and practices regarding dengue infection among public sector healthcare providers in Machala, Ecuador. Trop Dis Travel Med Vac. 2016;8:1-10. https://doi.org/10.1186/ s40794-016-0024-y.

12. Hassan SM, Haq AU, Byrd JA, Berhow MA, Cartwright AL, Bailey CA. Haemolytic and antimicrobial activities of saponin-rich extracts from guar meal. Food Chem. 2010;119:600-5. https://doi.org/10.1016/j.foodchem.2009.06. 066.

13. Hozumi T, Matsumoto T, Ooyama H, Namba T, Shiraki K, Hattori M, Kurokawa M, Kadota S. Antiviral agent containing crude drug. United States Patent US. 1995;5:411-733.

14. Jain PK, Rijhwani S. "Comparative GC-MS analysis of Cyamopsis tetragonoloba fruit extracts. Int J Pharm Sci Res. 2018;9:4236-42. https://doi.org/10.13040/IJPSR.0975-8232. 9(10).4236-42.

15. Katewa SS, Chaudhary BL, Jain A. Folk herbal medicines from tribal area of Rajasthan, India. J Ethnopharmacol. 2004;92:41-6. https://doi.org/10.1016/j.jep.2004.01.011.

16. Kaushik S, Kaushik S, Sharma V, Yadav JP. Antiviral and therapeutic uses of medicinal plants and their derivatives against dengue viruses. Pharmacogn Rev. 2018;12:177. https://doi.org/ 10.4103/phrev.phrev_2_18.

17. Kaushik S, Kaushik S, Yashika S, Kumar R, Yadav JP. The Indian perspective of COVID-19 outbreak. VirusDisease. 2020. https://doi.org/10.1007/s13337-020-00587-x.

18. Khare CP. Indian herbal remedies: rational Western therapy, ayurvedic, and other traditional usage Botany. Berlin: Springer; 2004. p. 171-2.

19. Kumar R, Nagpal S, Kaushik S, Mendiratta S. COVID-19 diagnostic approaches: different roads to the same destination. VirusDisease. 2020. https://doi.org/10.1007/s13337-02000599-7.

20. Laughlin CA, Morens DM, Cassetti MC, Costero-Saint Denis A, San Martin JL, Whitehead SS, Fauci AS. Dengue research opportunities in the Americas. J Infect Dis. 2012;206:1121-7. https://doi.org/10.1093/infdis/jis351.

21. Lee SH, Tang YQ, Rathkrishnan A, Wang SM, Ong KC, Manikam R, Payne BJ, Jaganath IB, Sekaran SD. Effects of cocktail of four local Malaysian medicinal plants (Phyllanthus spp.) against dengue virus 2. BMC Complement Alter Med. 2013; 13: 192. https://doi.org/10.1186/1472-6882-13-192.

22. Ling AP, Khoo BF, Seah CH, Foo KY, Cheah RK, Chye SM, Koh RY. Inhibitory activities of methanol extracts of Andrographis paniculata and Ocimum sanctum against dengue-1 virus. In: International Conference on Biological Environmental and Food Engineering: Bali, Indonesia. 2014; pp. 4-5. https://doi.org/ 10.15242/IICBE.C814013.

23. Maji AK, Pandit S, Banerji P, Banerjee D. Puerariatuberosa: a review on its phytochemical and therapeutic potential. Nat Prod Res. 2014;28:2111-27. https://doi.org/10.1080/14786419.2014. 928291.

24. Mohamed IK, Osama MA, Samiha M, Zahrat EM. Biochemical studies on Plantago major L. and Cyamopsis tetragonoloba L. Int J Biodivers Conserv. 2011;3:83-91.

25. Mukhtar HM, Ansari SH, Ali M, Bhat ZA, Bhat AZ, Naved T. Effect of aqueous extract of Cyamopsis tetragonoloba L. beans on blood glucose level in normal and alloxan-induced diabetic rats. Ind J Exp Biol. 2004;42:1212-5.

26. Orekhov AN, Ivanova EA. Cellular models of atherosclerosis and their implication for testing natural substances with antiatherosclerotic potential. Phytomed. 2016;23:1190-7. https://doi. org/10.1016/j.phymed.2016.01.003.

27. Rafatullah S, Al-Yahya MA, Al-Said MS, Taragan KA, Mossa JS. Gastric anti-ulcer and cytoprotective effects of Cyamopsis tetragonoloba ('Guar') in rats. Int J Pharmacogn. 1994;32:163-70. https://doi.org/10.3109/13880209409082988.

28. Rothan HA, Zulqarnain M, Ammar YA, Tan EC, Rahman NA, Yusof R. Screening of antiviral activities in medicinal plants extracts against dengue virus using dengue NS2B-NS3 protease assay. Trop Biomed. 2014; 31: 286-96. https://www.ncbi.nlm.nih. gov/pubmed/25134897. 
29. Santiago GA, Vergne E, Quiles Y, Cosme J, Vazquez J, Medina JF, Medina F, Colón C, Margolis H, Muñoz-Jordán JL. Analytical and clinical performance of the CDC Real Time RT-PCR assay for detection and typing of dengue virus. PLoSNeg Trop Dis. 2013;7:e2311. https://doi.org/10.1371/journal.pntd.0002311.

30. Sharma P, Hullatti K, Sharma S, Mukesh SS. Evaluation of antiinflammatory activity of Cyamopsis tetragonoloba seeds in rodents. J Pharm Re. 2010;3:163-5.

31. Sharma V, Chaudhry D, Kaushik S. Evaluation of clinical applicability of reverse transcription-loop-mediated isothermal amplification assay for detection and sub-typing of Influenza A viruses. J Virol Methods. 2018;253:18-25. https://doi.org/10. 1016/j.jviromet.2017.12.005.

32. Sharma V, Kaushik S, Kumar R, Yadav JP, Kaushik S. Emerging trends of Nipah virus: a review. Rev Med Virol. 2019;29:e2010. https://doi.org/10.1002/rmv.2010.

33. Sharma V, Kaushik S, Pandit P, Dhull D, Yadav JP, Kaushik S. Green synthesis of silver nanoparticles from medicinal plants and evaluation of their antiviral potential against chikungunya virus. Appl Microbiol Biotechnol. 2019;103:881-91. https://doi.org/10. 1007/s00253-018-9488-1.
34. Sharma V, Sharma M, Dhull D, Sharma Y, Kaushik S, Kaushik S. Zika virus: an emerging challenge to public health worldwide. Can J Microbiol. 2020;66:87-98. https://doi.org/10.1139/cjm2019-0331.

35. Tang LI, Ling AP, Koh RY, Chye SM, Voon KG. Screening of anti-dengue activity in methanolic extracts of medicinal plants. BMC Complement Altern Med. 2012;12:3. https://doi.org/10. $1186 / 1472-6882-12-3$

36. Wang ML, Morris JB. Flavonoid content in seeds of guar germplasm using HPLC. Plant Genet Resour. 2007;5:96-9. https://doi.org/10.1017/S1479262107672335.

37. Wintachai P, Kaur P, Lee RC, Ramphan S, Kuadkitkan A, Wikan N, Roytrakul S, Chu JJ, Smith DR. Activity of andrographolide against chikungunya virus infection. Sci Rep. 2015;5:14179. https://doi.org/10.1038/srep14179.

38. World Health Organization (WHO). Dengue control. World Health Organization. 2018. https://www.who.int/denguecontrol/ en/. Accessed 1 Aug 2019.

Publisher's Note Springer Nature remains neutral with regard to jurisdictional claims in published maps and institutional affiliations. 